\title{
Neuropsychiatric Symptoms, Endophenotypes, and Syndromes in Late-Onset Alzheimer's Disease: Focus on APOE Gene
}

\author{
Francesco Panza, ${ }^{1}$ Davide Seripa, ${ }^{1}$ Grazia D’Onofrio, ${ }^{1}$ Vincenza Frisardi, ${ }^{2}$ \\ Vincenzo Solfrizzi, ${ }^{2}$ Patrizia Mecocci, ${ }^{3}$ and Alberto Pilotto ${ }^{1}$ \\ ${ }^{1}$ Geriatric Unit and Gerontology-Geriatrics Research Laboratory, Department of Medical Sciences, \\ IRCCS “Casa Sollievo della Sofferenza”, San Giovanni Rotondo, 71013 Foggia, Italy \\ ${ }^{2}$ Department of Geriatrics, Center for Aging Brain, Memory Unit, University of Bari, 70121 Bari, Italy \\ ${ }^{3}$ Institute of Gerontology and Geriatrics, Department of Clinical and Experimental Medicine, University of Perugia, \\ 06100 Perugia, Italy
}

Correspondence should be addressed to Francesco Panza, geriat.dot@geriatria.uniba.it

Received 11 October 2010; Revised 11 February 2011; Accepted 11 February 2011

Academic Editor: Christiane Reitz

Copyright (c) 2011 Francesco Panza et al. This is an open access article distributed under the Creative Commons Attribution License, which permits unrestricted use, distribution, and reproduction in any medium, provided the original work is properly cited.

\begin{abstract}
Neuropsychiatric symptoms, previously denominated as behavioural and psychological symptoms of dementia, are common features of Alzheimer's disease $(\mathrm{AD})$ and are one of the major risk factors for institutionalization. At present, the role of the apolipoprotein $\mathrm{E}$ (APOE) gene in the development of neuropsychiatric symptoms in AD patients is unclear. In this paper, we summarized the findings of the studies of neuropsychiatric symptoms and neuropsychiatric syndromes/endophenotypes in AD in relation to APOE genotypes, with special attention to the possible underlying mechanisms. While some studies failed to find a significant association between APOE and neuropsychiatric symptoms in late-onset AD, other studies reported a significant association between the APOE $\varepsilon 4$ allele and an increase in agitation/aggression, hallucinations, delusions, and late-life depression or anxiety. Furthermore, some negative studies that focused on the distribution of APOE genotypes between AD patients with or without neuropsychiatric symptoms further emphasized the importance of subgrouping neuropsychiatric symptoms in distinct neuropsychiatric syndromes. Explanations for the variable findings in the existing studies included differences in patient populations, differences in the assessment of neuropsychiatric symptomatology, and possible lack of statistical power to detect associations in the negative studies.
\end{abstract}

\section{Introduction}

Dementia and age-related cognitive disorders are reaching epidemic proportions, given the significant increase in the aging population. Alzheimer's disease (AD), the most prevalent form of dementia [1], is a complex brain disorder that has effects on multiple cerebral systems, and characterized by relatively slow but progressive neurodegeneration and impairment in cognition, behavior, and functionality. Accurate $\mathrm{AD}$ epidemiological data have been recently released for the USA. The 2010 figures suggested that 5.3 million Americans have $\mathrm{AD}$ [2], with $>26$ million patients with $\mathrm{AD}$ worldwide, and an expected increase to more than 106 million by 2050 [3]. Neuropsychiatric symptoms, previously denominated as behavioral and psychological symptoms of dementia, are common features of $\mathrm{AD}[4,5]$ and are one of the major risk factors for institutionalization [6] as well as for increasing costs both in USA and Western countries $[7,8]$. Neuropsychiatric symptoms in AD include psychosis (delusions and hallucinations) as well as affective and behavioral changes such as depressive mood, anxiety, irritability/lability, apathy, euphoria, disinhibition, agitation/aggression, aberrant motor activities, sleep disturbance, and eating disorder [9]. Neuropsychiatric symptoms associated with AD tend to follow a trajectory of increasing severity over time, a feature they have in common with cognitive and functional decline. Neuropsychiatric symptoms may be associated to $\mathrm{AD}$ irrespective of cognitive impairment severity and may 
be the presenting complaint or may emerge in the course of the disease being important cause of a more rapid cognitive decline [9]. It has been estimated that up to $80 \%$ of patients with $\mathrm{AD}$ showed neuropsychiatric symptoms in the history of the disease $[9,10]$. Recently, the Behavioural Subgroup of the European Alzheimer's Disease Consortium has performed a factor analysis of the neuropsychiatric inventory (NPI) [11] in a homogeneous sample of patients with $\mathrm{AD}$, analyzing the largest $\mathrm{AD}$ population ever studied for this purpose [5]. The Behavioural Subgroup of the European Alzheimer's Disease Consortium identified 4 separate neuropsychiatric syndromes: hyperactive, psychotic, affective, and apathetic [5], providing also evidence of the relative consistency of neuropsychiatric syndromes across dementia subtypes, age and gender [12], and stressing the importance of thinking about neuropsychiatric syndromes instead of separate symptoms in $\mathrm{AD}$ patients.

The majority of $\mathrm{AD}$ cases are sporadic (i.e., without an apparent familial patterns of inheritance) compared with fewer than $5 \%$ of cases that are caused by autosomal dominant inheritance of mutations in presenilin 1, presenilin 2, or amyloid precursor protein [13]. Several genes have been identified as possible risk factors for the development of sporadic late-onset $\mathrm{AD}$, particularly the gene dose of apolipoprotein $\mathrm{E}$ (APOE) $\varepsilon 4$ alleles [13]. In fact, the APOE gene is the only globally valid genetic determinant of sporadic $\mathrm{AD}$ to have been unambiguously identified in 15 years of intensive research [14]. However, as with other multifactorial diseases, this systematic inability to detect new genetic determinants has prompted more comprehensive investigations using genome-wide association studies. Three large genome-wide association studies in this field were performed and reported that the clusterin (CLU), phosphatidylinositol binding clathrin assembly protein (PICALM), complement component $(3 \mathrm{~b} / 4 \mathrm{~b})$ receptor 1 (CR1), bridging integrator 1 (BIN1), and exocyst complex component 3like 2 (EXOC3L2) loci were associated with $\mathrm{AD}$ [15-17], in addition to the established APOE relationship. The genetic origin of the three common variants of the human APOE, known as E2, E3, and E4, was understood in 1981 [18], and since the mid of the 80 s these are probably the most studied protein variants in human races. A further study in 1982 proposed a nomenclature for these protein isoforms, to be identified as E2, E3, and E4 [19]. These important findings have led several researchers to the identification of the APOE encoding gene, that was recognized in 1982 [20], localized on chromosome 19 at locus q13.31 [21], and definitively sequenced [22]. Three years later, also the DNA encoding these isoforms was definitively sequenced [23] and named as $\varepsilon 2, \varepsilon 3$, and $\varepsilon 4$. The important implications of this study are the demonstration that these common gene variants were generated by the two single-nucleotide polymorphisms rs429358 and rs7412 in exon 4 of the APOE gene (AF261279) and that these three allelic forms of the APOE gene are indeed different haplotypes of the APOE gene, generated by the combination of the allele of these two single-nucleotide polymorphisms at the APOE locus [13].
Therefore, risk for late-onset $\mathrm{AD}$ is known to be associated with polymorphisms of the APOE gene; people with an $\varepsilon 4$ allele have an increased risk of both familial and sporadic forms, accounting for $20-50 \%$ of the attributable risk [13]. Nonetheless, APOE is neither necessary nor sufficient to cause $\mathrm{AD}$, and this is the main reason why APOE is classified as a risk factor for $\mathrm{AD}$ and not a causative one. Although this is currently a nonmodifiable risk factor, it has potential for modifying the impact of other factors, in particular vascular and lifestyle-related factors [24], implying that some interventions may perhaps best be restricted to people at genetic risk. At present, the role of the APOE polymorphism in the development of neuropsychiatric symptoms [2527] or neuropsychiatric syndromes/endophenotypes in $\mathrm{AD}$ patients is unclear [28-30]. It has been suggested that neuropsychiatric symptoms in $\mathrm{AD}$ may be influenced by the APOE polymorphism in various case-control studies $[25,26,28,29]$, but a recent longitudinal report showed a substantial lack of association between the APOE $\varepsilon 4$ allele and neuropsychiatric symptoms in $\mathrm{AD}$ after correction for multiple testing [27].

In this paper, we summarized the findings of the studies of neuropsychiatric symptoms and neuropsychiatric syndromes/endophenotypes in $\mathrm{AD}$ in relation to APOE genotypes from the English literature published before September 2010. We reviewed clinical and epidemiological studies from the international literature, including both cross-sectional and longitudinal studies that involved subjects aged 65 years and older. We searched through the PubMed database of NCBI (available at http://www.ncbi.nlm.nih.gov/) by author and the following keywords: neuropsychiatric symptoms, neuropsychiatric syndromes, neuropsychiatric endophenotypes, apolipoprotein E, APOE, dementia, Alzheimer's disease, late-life depression, late-life anxiety, affective syndromes, apathy, apathetic syndrome in dementia, agitation, aggressiveness, hyperactive syndrome in dementia, psychosis, psychotic syndrome in dementia, and behavioral and psychological symptoms of dementia. Special attention was paid to the possible mechanisms linked to the development of neuropsychiatric symptoms and neuropsychiatric syndromes/endophenotypes in $\mathrm{AD}$ in relation to APOE genotypes.

\section{APOE Genotypes and Affective Syndromes/Endophenotypes in AD: Late-Life Depression and Anxiety}

In adults older than 65 years, late-life depression refers to depressive syndromes encompassing both late-onset cases as well as early-onset cases that recur or continue into later years of life [31,32]. Late-life depressive syndromes often arise in the context of medical and neurological disorders [33]. The prevalence of major depressive disorder is about $17 \%$ in patients with $\mathrm{AD}[34]$ and is even higher in those with subcortical dementias [31, 32]. Furthermore, emerging research implicates also a consistent reciprocal relationship between late life anxiety and cognition $[35,36]$. In fact, anxiety disorders are the most common psychiatric diagnoses in 
late life with an estimated lifetime prevalence of $15.3 \%$ in older adults, surpassing population estimates for depressive disorders [37], and severe cognitive impairment [38]. There is evidence of more prevalent anxiety in cognitively impaired older adults, elevated anxiety related to poorer cognitive performance, and more severe anxiety symptoms predicting future cognitive decline [35].

Early studies examining the relationship between APOE genotypes and depression showed that the APOE $\varepsilon 4$ allele may be a risk factor for depressive symptoms in patients with $\mathrm{AD}$ and dementia [39-41], and other investigators have demonstrated combined risks of developing $\mathrm{AD}$ among those with late-life depression and APOE $\varepsilon 4$ allele in nondemented geriatric populations [42-45] (Table 1). These findings were confirmed in two very recent longitudinal population-based studies $[46,47]$. A recent study suggested that depression and APOE $\varepsilon 4$ genotype may be higher in women with $\mathrm{AD}$ but not in men [48]. Consistent with these previous studies demonstrating a relationship between APOE genotype and depression in $\mathrm{AD}[29-41,48]$, a recent report found that depressed $\mathrm{AD}$ patients had a significantly higher frequency of APOE $\varepsilon 4$ allele than nondepressed AD patients [49]. Also in this study the association between APOE genotype and depression in $\mathrm{AD}$ was primarily seen in women and not men, so conforming the results of a study showing an increased rate of the APOE $\varepsilon 4$ genotype in late-onset depressed women with $\mathrm{AD}$ relative to men [43]. Finally, in a very recent study, when $\mathrm{AD}$ patients were subdivided according to the European Alzheimer's Disease Consortium classification of neuropsychiatric syndromes, in APO $\varepsilon 4$-carriers there was an increased risk of affective syndrome (i.e., AD patients with the NPI symptoms depression and anxiety) [30]. These results on increased risk of an affective syndrome in $\mathrm{AD}$ patients APOE $\varepsilon 4$-carriers confirmed recent findings indicating that neuropsychiatric symptoms in $\mathrm{AD}$ are not purely an epiphenomenon of cognitive impairment but could be attributed to specific biological brain dysfunction, suggesting the presence of specific AD endophenotypes [28, 29, 50-52].

Despite these findings supporting an association between APOE and depression, several other published studies have not supported the notion that APOE $\varepsilon 4$ genotype influences depression in $\mathrm{AD}[25,58,66-69,71]$, also when specific $\mathrm{AD}$ endophenotypes were considered [28, 29] (Table 1). Other reports suggested that in $\mathrm{AD}$ the APOE $\varepsilon 4$ allele may be protective against depression [80] or that APOE $\varepsilon 2$-carriers may be at higher risk of depressive symptoms [53-55]. In addition, others have shown trends toward association between APOE genotype and depression but have rendered conclusions of no relationship $[60,77]$. One possible explanation for these contrasting findings may be the different sample size, with several studies including few depressed AD patients $[60,67,69]$, thus resulting in a different power to detect group differences. Also varying schemes for diagnosing depression in $\mathrm{AD}$ may be a source of variability $[25,68$, 71]. Another factor may be that the use of limited screening measures for determining depression could be leading to poorer diagnostic accuracy and thus different prevalence rates of depression in $\mathrm{AD}$ (range 11-50\%) [25, 49, 60]. Thus, the bulk of published studies reporting a lack of association between APOE $\varepsilon 4$ allele and depression in AD have suffered from small sample sizes, low reported prevalence rates for depression, very brief inventories of depressive symptoms, and/or low diagnostic rigor in the determination of the presence or absence of a Diagnostic and Statistical Manual of Mental Disorders-based diagnosis of depression.

Anxiety is most common among older subjects with mild cognitive impairment [81] and AD patients with a younger age at onset (under age 65) [82]. APOE e4 allele is a risk factor for developing $\mathrm{AD}$ at an earlier age [83] and might contribute to this effect [84]. Interestingly, APOE-null mice carrying the human $\varepsilon 4$ transgene had higher anxiety ratings than those expressing either wild-type murine APOE or the human $\varepsilon 3$ [73]. Very recently, these findings were also confirmed in female APOE TR mice expressing APOE under control of the mouse APOE promoter. APOE4 mice showed decreased activity levels and higher measures of anxiety than mice expressing APOE2 or APOE3 across all ages [85]. Notwithstanding the higher prevalence and symptom expression of anxiety disorders in late life, not all measures of neuropsychiatric symptoms in dementia reported in the literature include an assessment of anxiety [82]. Two studies using longitudinal assessments with the NPI found no association with anxiety $[25,65]$, and no association was found when assessed by the Behavioural Pathology in Alzheimer's Disease Rating Scale (BEHAVE-AD) in a cross-sectional study design [69] (Table 1). Consistent with the mouse studies [73, 85], APOE also has isoform-dependent effects on measures of anxiety in probable $\mathrm{AD}$ patients [73]. In particular, male $\varepsilon 4 / \varepsilon 4$ subjects had higher anxiety scores than gender-matched $\varepsilon 3 / \varepsilon 3$ subjects. In males, but not in females, subjects with $\varepsilon 4 / \varepsilon 4$ had also higher anxiety scores than those with $\varepsilon 3 / \varepsilon 4$ [73], suggesting that APOE3 can antagonize the effects of APOE4 on measures of anxiety in males but not in females. The anxiety scores did not correlate with the Mini-Mental State Examination scores [73]. Pritchard and colleagues did not support these findings using the same methods of analysis [27]. However, they found an association with the APOE $\varepsilon 3 / \varepsilon 4$ genotype, but not with the APOE $\varepsilon 4 / \varepsilon 4$ genotype or the e4 allele [27], so confirming a previous study in which anxiety appeared more frequently in APOE $\varepsilon 3 / \varepsilon 4$ demented patients, although this difference was not statistically significant [56]. Finally, when AD patients were subdivided according to the European Alzheimer's Disease Consortium classification of neuropsychiatric syndromes, for the affective syndrome (i.e., AD patients with the NPI symptoms depression and anxiety), these previous findings in $\mathrm{AD}$ and demented patients [27, 73, 74] were confirmed suggesting that the presence of an APOE $\varepsilon 4$ allele may be a risk factor also for anxiety symptoms [56].

\section{APOE and Apathy in AD}

Apathy has been increasingly recognized as a distinct psychiatric syndrome, and defined as a lack of motivation, evidenced by diminished goal-directed overt behavior, diminished goal-directed cognition, and diminished emotional 
TABle 1: Principal studies on the association of neuropsychiatric symptoms, endophenotypes, and syndromes with the apolipoprotein E (APOE) polymorphism in Alzheimer's disease $(\mathrm{AD})$ patients.

\begin{tabular}{|c|c|c|c|}
\hline Reference & Study sample & $\begin{array}{l}\text { Cognitive and neuropsychiatric } \\
\text { assessment }\end{array}$ & Principal results \\
\hline $\begin{array}{l}\text { Ramachandran } \\
\text { et al. [39] }\end{array}$ & $\begin{array}{l}46 \mathrm{AD} \text { patients; } \\
135 \text { controls, } \\
\text { restricted to APOE } \\
\varepsilon 3 / 3 \text { and } \varepsilon 3 / 4 \text { only }\end{array}$ & CDR, HAM-D, and SCID-DSM-III-R & $\begin{array}{l}\text { Depression rating greater with APOE } \varepsilon 3 / 4 \text { versus } \varepsilon 3 / 3 \\
\text { reference genotype. Psychosis greater with } \varepsilon 3 / 4 \text { versus } \\
\varepsilon 3 / 3 \text { reference genotype }\end{array}$ \\
\hline $\begin{array}{l}\text { Holmes et al. } \\
{[53-55]}\end{array}$ & $\begin{array}{l}164 \mathrm{AD} \text { patients } \\
232 \mathrm{AD} \text { patients } \\
210 \mathrm{AD} \text { patients }\end{array}$ & $\begin{array}{l}\text { BDRS } \\
\text { CAMDEX and MOUSEPAD }\end{array}$ & $\begin{array}{l}\text { APOE } \varepsilon 2 \text { allele significantly associated with depressive } \\
\text { symptoms. APOE } \varepsilon 2 \text { allele significantly associated also } \\
\text { with persecutory delusions }\end{array}$ \\
\hline $\begin{array}{l}\text { Cacabelos et al. } \\
{[40,56]}\end{array}$ & $\begin{array}{l}207 \text { demented } \\
\text { patients }\end{array}$ & $\begin{array}{l}\text { MMSE, GDS, ADAS, BCRS, FAST, } \\
\text { BEHAVE-AD, HAM-D, HAM-A, and } \\
\text { SDASDS }\end{array}$ & $\begin{array}{l}\text { Disorientation, agitation, and motor disorders were } \\
\text { slightly more frequent in demented patients with APOE } \\
\varepsilon 4 / \mathrm{e} 4 \text {, while anxiety and sleep disorders appeared more } \\
\text { frequently in APOE } \varepsilon 3 / \varepsilon 4 \text {. However, these differences } \\
\text { were not statistically significant }\end{array}$ \\
\hline
\end{tabular}

MMSE, BCRS, and HAM-D; the presence of rigidity, hypokinesia, tremor at rest, orofacial dyskinesia, myoclonus, Lehtovirta et al. $58 \mathrm{AD}$ patients and hallucinations, delusions, and different [57] 16 controls

kinds of paresis was recorded in the neurologic examination. The occurrence of epileptic seizures, hallucinations, and delusions was also inquired from the caregivers

\begin{tabular}{|c|c|c|c|}
\hline $\begin{array}{l}\text { Murphy et al. } \\
{[41]}\end{array}$ & $77 \mathrm{AD}$ patients & MMSE, TBDQ, and ADAS non-cog & APOE $\varepsilon 4$ allele associated with higher scores on TBDQ \\
\hline $\begin{array}{l}\text { Cantillon et al. } \\
{[58]}\end{array}$ & $162 \mathrm{AD}$ patients & MMSE and CSDD & $\begin{array}{l}\text { The APOE e } 4 \text { allele frequency was not increased in the } \\
\text { late-onset depression group among these AD patients }\end{array}$ \\
\hline Ballard et al. [80] & $51 \mathrm{AD}$ patients & $\begin{array}{l}\text { CAMCOG, CSDD, Burns symptom } \\
\text { checklist, and SCID-DSM-III-R }\end{array}$ & $\begin{array}{l}\text { Protective effect of APOE } \varepsilon 4 \text { allele against depression. } \\
\text { APOE } \varepsilon 4 \text {-carriers more likely to have future psychotic } \\
\text { episode }\end{array}$ \\
\hline \multirow[t]{2}{*}{$\begin{array}{l}\text { Forsell et al. } \\
{[60,61]}\end{array}$} & $\begin{array}{l}806 \text { participants } \\
\text { aging } 78 \text { years and } \\
\text { over }\end{array}$ & MMSE and CPRS & \multirow{2}{*}{$\begin{array}{l}\text { Depressed and nondepressed subjects had similar } \\
\text { APOE genotype distributions among the demented, } \\
\text { and among the nondemented, subjects. There was also } \\
\text { no statistical significant difference in APOE genotype } \\
\text { between subjects with and without psychotic } \\
\text { symptoms, stratified by dementia diagnosis }\end{array}$} \\
\hline & $\begin{array}{l}668 \text { participants } \\
\text { aging } 75 \text { years and } \\
\text { over }\end{array}$ & $\begin{array}{l}\text { Dementia was diagnosed using the } \\
\text { DSM-III-R criteria Psychotic symptoms } \\
\text { were defined according to DSM-IV } \\
\text { criteria }\end{array}$ & \\
\hline Lopez et al. [62] & 194 AD patients & $\begin{array}{l}\text { MMSE. BRS-CERAD, and } \\
\text { semi-structured psychiatric interview }\end{array}$ & $\begin{array}{l}\text { No evidence for an association of NPS with any specific } \\
\text { APOE genotype in probable AD patients }\end{array}$ \\
\hline $\begin{array}{l}\text { Lyketsos et al. } \\
{[63]}\end{array}$ & 120 AD patients & $\begin{array}{l}\text { Diagnoses for major and minor } \\
\text { depression according to DSM-IV, and } \\
\text { assessment of delusions or hallucinations } \\
\text { according to DSM-IV glossary definitions }\end{array}$ & $\begin{array}{l}\text { There was no association between APOE genotype and } \\
\text { the presence of NPS or the neuropsychiatric syndromes } \\
\text { examined. There was an interesting suggestion that the } \\
\text { e } 4 \text { allele may be protective against the development of } \\
\text { major depression; however, this association did not } \\
\text { reach statistical significance }\end{array}$ \\
\hline \multirow{2}{*}{$\begin{array}{l}\text { Hirono et al. } \\
{[64,65]}\end{array}$} & $228 \mathrm{AD}$ patients & MMSE, BEHAVE-AD, and NPI & \multirow{2}{*}{$\begin{array}{l}\text { The APOE } \varepsilon 4 \text { allele had no effect on the manifestation } \\
\text { of delusions, hallucinations, depression, or other NPS } \\
\text { in } \mathrm{AD}\end{array}$} \\
\hline & $175 \mathrm{AD}$ patients & $\begin{array}{l}\text { MMSE, CDR, and the Japanese } \\
\text { versionlof the NPI }\end{array}$ & \\
\hline Levy et al. [25] & $605 \mathrm{AD}$ patients & MMSE and NPI & $\begin{array}{l}\text { Among patients with comparable disease severity, the } \\
\text { APOE } \varepsilon 4 \text { allele does not confer additional psychiatric } \\
\text { morbidity }\end{array}$ \\
\hline $\begin{array}{l}\text { Harwood et al. } \\
{[66]}\end{array}$ & $501 \mathrm{AD}$ patients & $\begin{array}{l}\text { MMSE, HAM-D, and structured } \\
\text { interview for specific delusions and } \\
\text { hallucinations }\end{array}$ & Increased risk for psychosis with APOE $\varepsilon 4$ allele \\
\hline $\begin{array}{l}\text { Müller-Thomsen } \\
\text { et al. [48] }\end{array}$ & 137 AD patients & MMSE and MADRS & $\begin{array}{l}\text { Overrepresentation of the APOE } \varepsilon 4 \text { allele in female AD } \\
\text { patients }\end{array}$ \\
\hline
\end{tabular}

Cognitive and neuropsychiatric symptoms and signs were not related to the APOE genotype 
Table 1: Continued.

\begin{tabular}{|c|c|c|c|}
\hline Reference & Study sample & $\begin{array}{l}\text { Cognitive and neuropsychiatric } \\
\text { assessment }\end{array}$ & Principal results \\
\hline Liu et al. [67] & 149 AD patients & $\begin{array}{l}\text { CASI, CDR, HAM-D, and } \\
\text { SCID-DSM-III-R }\end{array}$ & $\begin{array}{l}\text { No evidence of an association between depression in } \\
\text { AD patients and presence or absence of the APOE } \varepsilon 4 \text { or } \\
\varepsilon 2 \text { allele }\end{array}$ \\
\hline $\begin{array}{l}\text { Scarmeas et al. } \\
{[68]}\end{array}$ & $87 \mathrm{AD}$ patients & $\begin{array}{l}\text { MMSE, CUSPAD, BDRS, and } \\
\text { SCID-DSM-III-R }\end{array}$ & $\begin{array}{l}\text { APOE } \varepsilon 4 \text { alleles associated with risk for incident } \\
\text { delusions. APOE } \varepsilon 4 / \varepsilon 4 \text { predicted protective effect } \\
\text { against hallucinations }\end{array}$ \\
\hline $\begin{array}{l}\text { Gabryelewicz } \\
\text { et al. [69] }\end{array}$ & 139 AD patients & MMSE, GDS, and BEHAVE-AD & $\begin{array}{l}\text { The APOE e } 4 \text { allele had no effect on the behavioural } \\
\text { changes in AD }\end{array}$ \\
\hline Sweet et al. [70] & $316 \mathrm{AD}$ patients & $\begin{array}{l}\text { MMSE, BRS-CERAD, and } \\
\text { SCID-DSM-III-R }\end{array}$ & $\begin{array}{l}\text { There was no significant association of APOE genotype } \\
\text { with time to psychosis onset and no significant } \\
\text { interaction of this genotypes with time to psychosis } \\
\text { onset }\end{array}$ \\
\hline $\begin{array}{l}\text { Craig et al. } \\
{[26,71]}\end{array}$ & $\begin{array}{l}400 \text { AD patients } \\
404 \text { AD patients }\end{array}$ & $\begin{array}{l}\text { NPI with caregiver distress } \\
\text { MMSE and NPI with caregiver distress }\end{array}$ & $\begin{array}{l}\text { Increase in agitation/aggression in patients with the } \\
\text { APOE } \varepsilon 4 \text { allele, while APOE genotype created no } \\
\text { additional risk for depressive symptoms in AD }\end{array}$ \\
\hline Chang et al. [72] & $135 \mathrm{AD}$ patients & CASI, CDR, and SCID-DSM-III-R & $\begin{array}{l}\text { APOE } \varepsilon 4 \text { significantly associated with hallucinations } \\
\text { and delusions }\end{array}$ \\
\hline $\begin{array}{l}\text { Robertson et al. } \\
{[73]}\end{array}$ & $125 \mathrm{AD}$ patients & CSDD and NPI & $\begin{array}{l}\text { Greater level of anxiety in APOE } \varepsilon 4 / \varepsilon 4 \text { versus } \varepsilon 3 \varepsilon / 3 \\
\text { bearers in both genders and versus } \varepsilon 3 / \varepsilon 4 \text { in males only }\end{array}$ \\
\hline Borroni et al. [28] & ] $232 \mathrm{AD}$ patients & $\begin{array}{l}\text { By Principal Component Analysis of NPI } \\
\text { symptoms, four endophenotypes were } \\
\text { identified, these were termed "psychosis," } \\
\text { "moods," "apathy," and "frontal" }\end{array}$ & $\begin{array}{l}\text { APOE genotype did not correlate with any } \\
\text { neuropsychiatric endophenotype }\end{array}$ \\
\hline
\end{tabular}

By Principal Component Analysis of NPI symptoms, four interpretable components were identified: behavioral Hollingworth dyscontrol (euphoria, disinhibition, et al. [29] 1,120 AD patients aberrant motor behavior, and sleep and appetite disturbances), psychosis (delusions and hallucinations), mood (depression, anxiety, and apathy), and agitation (aggression and irritability)

\begin{tabular}{lll}
$\begin{array}{l}\text { Monastero et al. } \\
{[74]}\end{array}$ & 197 AD patients & MMSE and NPI \\
\hline $\begin{array}{l}\text { Spalletta et al. } \\
{[59]}\end{array}$ & 171 AD patients & MMSE and NPI \\
\hline
\end{tabular}

The presence of apathy was significantly associated with the APOE $\varepsilon 4$ allele independently from age, education, sex, and duration of disease

The association between NEUROPSYCHIATRIC SYMPTOMS and APOE $\varepsilon 4$ allele in AD was confirmed for delusions only

Pritchard et al. 388 AD patients MMSE and NPI
[27]
Protective effect of the APOE $\varepsilon 3 / \varepsilon 4$ genotype that was significantly associated with hallucinations symptoms. $\mathrm{APOE} \varepsilon 3 / \varepsilon 4$ genotype is significantly associated with anxiety
van der Flier et al.
[75]
110 AD patients
MMSE and NPI

Delusions and agitation/aggression were more common and severer among homozygous APOE $\varepsilon 4$ carriers than among heterozygous or APOE- $\varepsilon 4$-negative patients

Zdanys et al. [76] $266 \mathrm{AD}$ patients $\quad$ MMSE, ADL, IADL, and NPI

APOE $\varepsilon 4$ was significantly associated with psychotic symptoms, adjusting for age, sex, education, and MMSE score

Delano-Wood
et al. [49]

Higher prevalence rate of the APOE $\varepsilon 4$ genotype in the depressed group compared to the nondepressed AD patients. This effect was primarily accounted for by women 
TABle 1: Continued.

\begin{tabular}{|c|c|c|c|}
\hline Reference & Study sample & $\begin{array}{l}\text { Cognitive and neuropsychiatric } \\
\text { assessment }\end{array}$ & Principal results \\
\hline Chopra et al. [77] & $\begin{array}{l}175 \text { cognitively } \\
\text { impaired subjects, } \\
\text { of which } 92 \mathrm{AD} \text { and } \\
80 \text { MCI patients }\end{array}$ & MMSE, GDS-15, and NPI & $\begin{array}{l}\text { The difference in the proportion of participant } \\
\text { reporting "low energy" at GDS- } 15 \text { between the three } \\
\text { APOE } \varepsilon 4 \text { allele frequency groups approached statistical } \\
\text { significance }\end{array}$ \\
\hline $\begin{array}{l}\text { Del Prete et al. } \\
\text { [78] }\end{array}$ & $53 \mathrm{AD}$ patients & MMSE and NPI & $\begin{array}{l}\text { Patients with APOE } 4 \text { allele showed a wider range of } \\
\text { NEUROPSYCHIATRIC SYMPTOMS when compared } \\
\text { to noncarriers and higher scores for hallucinations and } \\
\text { aberrant motor behaviors. Over time, } \varepsilon 4 \text { carriers } \\
\text { showed an increase/delayed onset in some symptoms } \\
\text { and a parallel decrease in others, while noncarriers } \\
\text { presented an undifferentiated worsening of } \\
\text { symptomatology }\end{array}$ \\
\hline Woods et al. [79] & $\begin{array}{l}36 \text { demented } \\
\text { patients }\end{array}$ & MMSE and $\mathrm{mABRS}$ & $\begin{array}{l}\text { Patients with an APOE } \varepsilon 4 \text { allele had a significant } \\
\text { increase in their observed NEUROPSYCHIATRIC } \\
\text { SYMPTOMS, including restlessness and vocalizations, } \\
\text { compared to those who did not have an APOE } \varepsilon 4 \text { allele } \\
\text { present }\end{array}$ \\
\hline
\end{tabular}

MMSE, ADL, IADL, CIRS, and

NPI. Furthermore, AD patients with NEUROPSYCHIATRIC SYMPTOMS were further D'Onofrio et al. $201 \mathrm{AD}$ patients and [30] 121 controls subdivided in four groups according to the EADC classification of neuropsychiatric syndromes in AD: hyperactive, psychotic, affective, and apathetic
No difference in the distribution of APOE genotypes was found between $\mathrm{AD}$ patients with and without NEUROPSYCHIATRIC SYMPTOMS. In AD patients APOE $\varepsilon 4$-carriers, there was an increased risk of affective and apathetic syndromes

CDR: Clinical Dementia Rating scale; HAM-D: Hamilton rating scale for depression; SCID-DSM-III-R: Structured Clinical Interview for Diagnostic and Statistical Manual of Mental Disorders-III-revised; BDRS: Blessed Dementia Rating Scale; CAMDEX: The Cambridge examination for mental disorders of the elderly; MOUSEPAD: Manchester and Oxford universities scale for the psychopathological assessment of dementia; MMSE: Mini Mental State Examination; GDS: Global Deterioration Scale; ADAS: Alzheimer's Disease Assessment Scale; BCRS: Brief Cognitive Rating Scale; FAST: Functional Assessment Stages; BEHAVE-AD: Behavioural Pathology in Alzheimer's Disease Rating Scale; HAM-A: Hamilton rating scale for anxiety; SDASDS: Senile Dementia-Associated Sleep Disorders Scale; TBDQ: time-based behavioural disturbance questionnaire (does patient display any of following symptoms in 1 month prior to assessment (combativeness, agitation, wandering, incoherent speech, hallucinations, confusion, and disorientation); ADAS non-cog: Alzheimer's disease assessment scale noncognitive subscale; CSDD: Cornell Scale for Depression in Dementia; CAMCOG: Cambridge assessment for mental disorders in the elderly; CPRS: Comprehensive Psychopathological Rating Scale; BRS-CERAD: Behavior Rating Scale for dementia of the Consortium to Establish a Registry for Alzheimer's Disease; DSM-IV: Diagnostic and Statistical Manual of Mental Disorders-IV; NPI: Neuropsychiatry Inventory; MADRS: Montgomery-Asberg Depression rating Scale; CASI: Cognitive Abilities Screening Instrument; CUSPAD: Colombia University Scale for Psychopathology in AD; ADL: activities of daily living; IADL: instrumental activities of daily living; GDS-15: 15-item Geriatric Depression Scale; MCI: mild cognitive impairment; mABRS: modified Agitated Behavior Rating Scale; CIRS: Cumulative Illness Rating Scale; EADC: European Alzheimer's Disease Consortium.

concomitants of goal-directed behavior [86, 87]. To date, there is no clear consensus on the definition of apathy, and it is not included in the glossary of the Diagnostic and Statistical Manual of Mental Disorders-IV [88] and mentioned merely as a nonspecific symptom of several disorders. Anhedonia or loss of interest or pleasure can be used as a principal symptom to diagnose major depressive disorder instead of or along with depressed mood. Because other criteria for Diagnostic and Statistical Manual of Mental Disorders-IV diagnosis of major depressive disorder [88] such as fatigue, hypersomnia or insomnia, loss of appetite, weight loss, and diminished ability to concentrate are prevalent among demented patients, a demented patient with apathy may be misdiagnosed as having major depressive disorder even in the absence of dysphoria [89]. This diagnostic challenge stems from the apparent overlap between apathy and depression [90]. Apathy has been reported to be common in AD outpatients, and the reported prevalence for apathy using the NPI was between $32.1 \%$ and $93.2 \%$ [91, 92] . Also the relationship between the APOE e4 allele and the apathetic syndrome and/or the apathy symptom was studied [28-30, 36-38, 70, 74, 75, 93], although it has not been as thoroughly investigated as for depression or psychosis. In a sample of 197 subjects with probable $\mathrm{AD}$, the presence of apathy was significantly associated with the APOE e4 allele independently from age, education, sex, duration of disease, Mini-Mental State Examination score, and other neuropsychiatric symptoms [74]. Furthermore, the recent results on an increased risk of the European Alzheimer's Disease Consortium apathetic syndrome (i.e., NPI symptoms apathy and eating abnormalities) in AD patients APOE $\varepsilon 4-$ carriers [30] confirmed these previous findings suggesting a relationship between the APOE $\varepsilon 4$ allele and apathy in patients with $\mathrm{AD}$ [74], although other studies did not show 
any correlation between apathy endophenotypes [28, 29] or NPI apathy symptom [75] and APOE genotypes (Table 1).

\section{APOE and Psychotic Symptoms and Syndromes/Endophenotypes in AD}

Among neuropsychiatric symptoms in $\mathrm{AD}$, major attention has been dedicated to psychotic symptoms, that typically consist of delusions and/or hallucinations [94]. The prevalence of psychosis is quite substantial, with estimates for delusions in $\mathrm{AD}$ ranging from 9.3\% to 63\% (median 36\%) and estimates for hallucinations ranging from $4 \%$ to $41 \%$ (median 18\%) [95]. However, psychosis proved to be a coherent grouping of psychiatric symptoms in $\mathrm{AD}$ in studies using cluster and factor analysis [94, 96]. Therefore, it has been reported that $\mathrm{AD}$ patients with psychosis $(\mathrm{AD}+$ psychosis, $\mathrm{AD}+\mathrm{P}$ ) may be clinically different from $\mathrm{AD}$ $[93,94,97]$. Indeed, an increased familial risk for the $\mathrm{AD}+\mathrm{P}$ endophenotype has been observed [70], suggesting heritability $[88,98]$ and thus a possible genetic component of this clinical feature. In fact, genes that have been implicated in psychosis of $\mathrm{AD}$ include those for dopamine-3 and serotonin-2A receptors [98]. Major attention has been dedicated to psychotic episodes in relation to APOE genotypes, and a number of investigations have examined whether the APOE $\varepsilon 4$ allele might contribute to the $\mathrm{AD}+\mathrm{P}$ endophenotype [98]. Among initial studies conducted in unrelated $\mathrm{AD}+\mathrm{P}$ and $\mathrm{AD}$ without psychosis subjects, one large [66] and two smaller studies $[39,80]$ have found an association of APOE $\varepsilon 4$ allele and the AD $+\mathrm{P}$ endophenotype. However, most successive reports have found no association of the APOE e4 allele with AD + P $[25,27,40,56,61,99,100]$ (Table 1), suggesting that it may be necessary to operate a distinction among different psychotic symptoms in $\mathrm{AD}$ in relation to APOE polymorphism. However, also association studies with hallucinations have been contradictory, with two copies of $\varepsilon 4$ being reported as protective [68], $\varepsilon 4$ being associated with increased risk [72], and hallucinations appeared to increase with more $\varepsilon 4$ alleles [101] or also, in a small longitudinal study, to decrease 1 year after diagnosis in $\mathrm{AD}$ patients with one $\varepsilon 4$ allele [78]. The association of hallucinations in $\mathrm{AD}$ with the e3/E4 genotype [27] also added further inconsistencies to reported findings. Hallucinations are sometimes incorporated into a measure of psychosis, but also these studies have again been inconsistent, with significant associations being reported for the $\varepsilon 4$ allele [66] and for $\varepsilon 3 / \varepsilon 4$ versus $\varepsilon 4 / \varepsilon 4$ carriers [39]. Furthermore, when the outcome was the presence of delusions in $\mathrm{AD}$ patients, in a longitudinal study, one $\varepsilon 4$ allele carried 2.5-fold risk whereas the presence of two $\varepsilon 4$ alleles carried 5.6-fold risk for development of delusions during a 9.3-year followup [68]. These findings were confirmed in other two longitudinal studies in which the presence of the APOE $\varepsilon 4$ allele carried a 3.4-fold risk for developing delusions [72] and the presence of one e4 allele, 1 year after diagnosis, showed a moderate, but significant, increase in delusions [78]. Also in crosssectional studies, APOE $\varepsilon 4$ allele possession was associated with increased levels of delusions within the last month from the first visit and with the presence of categorical delusions at the early stage until the first visit [59], delusions appeared to increase with more $\varepsilon 4$ alleles [101] and $\varepsilon 4 / \varepsilon 4$ genotype [75], and $\varepsilon 4$ was preferentially associated with delusions also in a large sample of $\mathrm{AD}$ patients from the USA [76]. However, when $\mathrm{AD}$ patients were subdivided according to the European Alzheimer's Disease Consortium classification of neuropsychiatric syndromes, for psychotic syndrome, including $\mathrm{AD}$ patients with delusions, hallucinations, and night-time disturbances, no association was found between APOE polymorphism and this neuropsychiatric syndrome [30]. These findings were consistent with those of a larger number of studies in which no association was found between APOE genotypes and the psychotic endophenotype $[28,29]$ or also single psychotic symptoms or measures incorporating these symptoms, that is, hallucinations $[26,57$, 62-65, 69] and delusions [62, 65] (Table 1).

\section{APOE, Agitation/Aggressiveness, and Hyperactive Syndrome/Endophenotype in AD}

Agitation/aggressiveness differs from psychosis and depression of $\mathrm{AD}$ in that it may be conceptualized as a single symptom or a symptom complex [94]. The prevalence of agitation in dementia ranges from $20 \%$ to $60 \%$, depending on diagnostic definitions used and the population studied [102]. A formalized definition of agitation was proposed as "inappropriate verbal, vocal, or motor activity that is not judged by an outside observer to be an obvious outcome of the needs or confusion of the individual" [103]. Agitation/ aggressiveness in dementia often co-occurs with psychosis and depression. There is substantial evidence that verbal agitation is associated with depression, and there may be some relationship to delusions [94, 104]. Psychosis, particularly delusions, and depression occur with increased frequency in aggressive patients and may be a causative factor [105]. Also the symptom complex agitation/aggressiveness has been linked to APOE genotypes. Agitation and disorientation were more common in demented patients $\varepsilon 4 / \varepsilon 4$ carriers, whereas anxiety and sleep disorders were more common in $\varepsilon 3 / \varepsilon 4$ carriers, although these differences were not statistically significant $[40,56]$. In another report, it was noted that the presence of the $\varepsilon 4$ allele was associated with increased combativeness, agitation, wandering, and confusion [41]. These findings were confirmed in two other recent studies in which the APOE $\varepsilon 4$ allele has been associated with agitation/aggressiveness using the Neuropsychiatric Inventory Caregiver Distress Scale (NPI-D) [26, 75], and in a recent report in which the presence of the APOE e4+ genotype increased the risk for agitated behaviour, including restlessness and vocalizations, in nursing home residents with dementia [79] (Table 1). However, when AD patients were subdivided according to the European Alzheimer's Disease Consortium classification of neuropsychiatric syndromes, for hyperactive syndrome, including $\mathrm{AD}$ patients with agitation, euphoria, disinhibition, irritability, and aberrant motor behaviour, no association was found between APOE 
genotypes and this neuropsychiatric syndrome, as also was found for psychotic syndrome [30]. These findings on the European Alzheimer's Disease Consortium hyperactive syndrome were similar to previous negative results in endophenotype [29], single symptom approach [25, 65], and in a study evaluating risk for incident neuropsychiatric symptoms in a prospectively followed cohort [68] (Table 1).

\section{Mechanisms Linking Neuropsychiatric Symptoms and Syndromes/Endophenotypes with APOE Genotypes in AD}

The present reviewed evidence on a possible role of the APOE polymorphism on the development of neuropsychiatric symptoms in $\mathrm{AD}$ patients confirmed that genetic factors may account for some of the neuropsychiatric heterogeneity associated with $\mathrm{AD}[106,107]$. The role of APOE in $\mathrm{AD}$-related depression is still controversial, and additional research is needed [108]. However, recent evidence has been accumulating to suggest that APOE may be linked to vascular risk factors in late life and, in turn, may be associated with depression. Indeed, it has been posited that the $\varepsilon 4$ allele may be a predisposing genetic marker for ischemic cerebrovascular disease [109] given its association with hyperlipidemia [110], atherosclerosis [111], myocardial infarction [112], and subcortical white matter lesion pathology [113]. Some latelife depressive syndromes might predispose, precipitate, or perpetuate by cerebrovascular disease, the so-called "vascular depression" hypothesis $[114,115]$. In fact, a history of stroke was associated with a 3-4-fold increased risk of apathy and depression in $\mathrm{AD}$ [116], and cerebrovascular disease has previously been linked to depression in several studies of individuals with dementia [117]. In addition, the APOE $\varepsilon 4$ allele may increase the odds that older depressed patients develop mild cognitive impairment [118]. Finally, it has been proposed that, for those carrying a copy of the $\varepsilon 4$ allele, the destructive effect of subtle, underlying vascular risk factors, may be enhanced [113]. Furthermore, the APOE $\varepsilon 4$ allele appears to be less efficient than other isoforms in inducing cholesterol transport [119], which may have an important role in maintaining the integrity of membranes, and in synaptic plasticity. Thus, it appears that the APOE $\varepsilon 4$ allele is associated with impaired response to cerebral damage and diminished capacity for neuronal repair [120, 121] and that this poorer neuronal reparative capacity may be implicated in the development of cognitive decline and depression in older adults with the APOE $\varepsilon 4$ genotype. Finally, for affective syndromes and/or symptoms in AD, also the mechanisms underlying the suggested association between late-life anxiety and $\mathrm{APOE}$ in $\mathrm{AD}$ are, at present, not completely understood $[73,84,85]$. Interestingly, higher measures of anxiety were reported in male mice lacking murine APOE $\left(\mathrm{APOE}^{-/}\right)$than in sex-matched wild-type controls $[73,84]$. There were isoform-dependent effects of $\mathrm{APOE}$ on measures of anxiety in male $\mathrm{APOE}^{-/-}$and APOE3 and APOE4 mice expressing human APOE in neurons under control of the neuron-specific enolase (NSE) promoter or in astrocytes under control of the glial fibrillary acidic protein (GFAP) promoter $[73,84] . \mathrm{APOE}^{-/-}$and APOE4 male mice showed increased measures of anxiety, whereas APOE3 mice behaved like wild-type controls [73, 84]. Very recently, these findings were also confirmed in female APOE TR mice expressing APOE under control of the mouse APOE promoter [85]. APOE4 mice showed decreased activity levels and higher measures of anxiety than mice expressing APOE2 or APOE3 across all ages [85].

The association of cerebrovascular disease with apathy may reflect stroke-related damage to areas of the prefrontal cortex or related neural pathways, involved in the planning and execution of goal-directed behavior [122]. In fact, apathy is associated with frontal and subcortical pathology $[123,124]$, and more severe apathy has been related with a severe impairment of frontal executive functions [125]. Functional imaging studies revealed that apathy in $A D$ is related to dysfunction of the right temporoparietal and anterior cingulate cortices [122, 123], regions involved in frontal-subcortical networks. A recent neuropathological study reported a significant relationship between chronic apathy and anterior cingulated cortex tangle pathology [124]. Apathetic patients with AD treated with cholinesterase inhibitors showed a significant reduction in apathy [126]. This is probably related to loss of nucleus basalis of Meynert cholinergic input to prefrontal and subcortical regions [122]. Interestingly, the APOE $\varepsilon 4$ allele has been associated with a severe loss of cholinergic activity in the frontal cortex [127] and with enhanced $\beta$-amyloid deposition in the frontal region of nondemented presenile subjects [128].

Although the $\varepsilon 4$ allele has been shown to promote the neuropathological features of $\mathrm{AD}$, including $\beta$-amyloid deposition $[129,130]$ and neurofibrillary tangle formation $[129,130]$, attempts to relate these features to psychotic symptoms in $\mathrm{AD}$ have yielded conflicting results [131, 132]. Therefore, neuropsychiatric symptomatology could be associated with more severe neuropathological changes, although there is no clear consensus on this. Furthermore, the $\varepsilon 4$ allele has been associated with more profound deficits in cholinergic neurons, in particular in the frontal cortex [127] and medial temporal lobe [133], whereas the development of neuropsychiatric symptoms in $\mathrm{AD}$ appears to be related to specific neurotransmitter imbalances, notably acetylcholine [134]. Psychotic manifestations in AD have been associated with pathology in the temporal lobe and hippocampus $[131,135]$. One single photon emission computed tomography study has suggested that delusions in $\mathrm{AD}$ may be associated with hypoperfusion in the temporal lobes [136], and some [137] but not all [138] functional imaging studies have shown that $\mathrm{AD}$ patients who carry the $\varepsilon 4$ allele have reduced temporal lobe function. The structural magnetic resonance imaging literature is more unified in showing greater medial temporal lobe atrophy in association with the $\varepsilon 4$ allele in AD [139-141]. It is conceivable that the detected association between APOE genotype and psychotic symptom, particularly delusions, might reflect neuropathology more heavily concentrated in the temporal lobe. Finally, also the mechanisms of the possible association between APOE and aggressive/agitated behaviour in $\mathrm{AD}$ are unclear. APOE is associated with more rapid progression as 
measured by single photon emission computed tomography and higher tangle burden in the brain $[130,138,142$, 143]. The accepted spread of neuropathological damage seen in $\mathrm{AD}$, from the hippocampus to frontal-temporalparietal regions, may encourage the development of those behavioural symptoms that not only localize regionally within the brain but are dependent on progressive neuronal loss and amyloid deposition away from the mesial temporal lobe. Frontal involvement is the best neuroanatomical correlate for aggression and agitation with secondary disruption of the serotonergic and dopaminergic systems [144-147]. High agitation scores correlate with bilateral orbitofrontal and left anterior cingulated tangle burden [144] and with left fronto-temporal hypoperfusion on single photon emission computed tomography scanning [145].

\section{Conclusions}

Environmental factors that have been associated with lateonset $\mathrm{AD}$ include depressive syndromes, various vascular risk factors, level of education, head trauma, and dietary factors. This complexity may help explain their high prevalence from an evolutionary perspective, but the etiologic complexity makes identification of disease-related genes much more difficult [148]. The "endophenotype" approach is an alternative method for measuring phenotypic variation that may facilitate the identification of susceptibility genes for complexly inherited traits [148]. The association of the APOE genotypes with neuropsychiatric symptoms or neuropsychiatric syndromes and endophenotypes in AD appeared to be still unclear. Neuropsychiatric symptoms in different times could coexist in a single patient showing a very complex psychological profile. The discrepancy in dementia syndromes between the occurrence of neuropsychiatric symptoms from rather linear cognitive decline implies independent pathophysiological pathways between these symptoms. In particular, contrasting findings existed on the possible association between affective symptoms or syndromes in $\mathrm{AD}$ and $\mathrm{APOE}$ genotypes, with studies with measures of late-life depressive syndromes and symptoms more frequent than studies that focused on late-life anxiety. At present, there is only limited evidence of an increased risk of apathy or agitated behaviour linked to the presence of APOE $\varepsilon 4$ allele in AD patients. Furthermore, some studies have found an association between APOE $\varepsilon 4$ allele and the $\mathrm{AD}$ plus psychosis endophenotype, with several studies suggesting a possible role of this polymorphism when the outcome was the presence of delusions in $\mathrm{AD}$ patients rather than of hallucinations. The fact that some studies assessing neuropsychiatric symptoms in relation to APOE status often analyzed the dichotomized APOE $\varepsilon 4$ status rather than the number of APOE e4 alleles may partially account for these contrasting findings, suggesting a methodological limit for the correct evaluation of predisposing factors and the pathogenetic basis of neuropsychiatric symptoms in AD. Discrepant findings may be due also to other factors including small sample sizes, differences in sample compositions (e.g., general "dementia" groups versus strictly diagnosed patients with "probable AD," with some of the studies including patients with Lewy body disease), the use of very brief, wideranging, or unstructured psychopathology inventories, and possible lack of statistical power to detect associations in the negative studies. Furthermore, some negative studies that focused on the distribution of APOE genotypes between $\mathrm{AD}$ patients with or without neuropsychiatric symptoms further emphasized the importance of subgrouping these symptoms in distinct neuropsychiatric syndromes, suggesting also genetic basis for individual neuropsychiatric symptoms. In addition, many of the above studies did not control for potential confounding variables. Most important, many reviewed studies were cross-sectional, whereas it would be of paramount importance to evaluate the risk for incident neuropsychiatric symptoms in relation to the APOE genotypes in prospectively followed cohorts of $\mathrm{AD}$ patients. In fact, crosssectional studies have limitations in interpreting the causal relationship between APOE and neuropsychiatric symptoms or neuropsychiatric syndromes/endophenotypes. Further longitudinal studies on larger sample of patients are needed to clarify the possible role of this gene in neuropsychiatric symptoms or neuropsychiatric syndromes/endophenotypes in $\mathrm{AD}$.

\section{Acknowledgment}

This work was fully supported by "Ministero della Salute," IRCCS Research Program, Ricerca Corrente 2009-2011, Linea no. 2 "Malattie complesse."

\section{References}

[1] C. Qiu, D. De Ronchi, and L. Fratiglioni, "The epidemiology of the dementias: An update," Current Opinion in Psychiatry, vol. 20, no. 4, pp. 380-385, 2007.

[2] Alzheimer's Association, "Alzheimer's disease facts and figures," Alzheimers \& Dementia, vol. 6, no. 2, pp. 158-194, 2010.

[3] R. Brookmeyer, E. Johnson, K. Ziegler-Graham, and H. M. Arrighi, "Forecasting the global burden of Alzheimer's disease," Alzheimer's and Dementia, vol. 3, no. 3, pp. 186-191, 2007.

[4] M. S. Mega, J. L. Cummings, T. Fiorello, and J. Gornbein, "The spectrum of behavioral changes in Alzheimer's disease," Neurology, vol. 46, no. 1, pp. 130-135, 1996.

[5] P. Aalten, F. R. J. Verhey, M. Boziki et al., "Neuropsychiatric syndromes in dementia: results from the European Alzheimer disease Consortium: part I," Dementia and Geriatric Cognitive Disorders, vol. 24, no. 6, pp. 457-463, 2007.

[6] C. Steele, B. Rovner, G. A. Chase, and M. Folstein, "Psychiatric symptoms and nursing home placement of patients with Alzheimer's disease," American Journal of Psychiatry, vol. 147, no. 8, pp. 1049-1051, 1990.

[7] D. L. Murman, Q. Chen, M. C. Powell, S. B. Kuo, C. J. Bradley, and C. C. Colenda, "The incremental direct costs associated with behavioral symptoms in AD," Neurology, vol. 59, no. 11, pp. 1721-1729, 2002.

[8] N. Herrmann, K. L. Lanctôt, R. Sambrook et al., "The contribution of neuropsychiatric symptoms to the cost of dementia care," International Journal of Geriatric Psychiatry, vol. 21, no. 10, pp. 972-976, 2006. 
[9] S. I. Finkel, J. Costa e Silva, G. Cohen, S. Miller, and N. Sartorius, "Behavioral and psychological signs and symptoms of dementia: a consensus statement on current knowledge and implications for research and treatment," International Psychogeriatrics, vol. 8, supplement 3, pp. 497-500, 1996.

[10] C. G. Lyketsos, O. Lopez, B. Jones, A. L. Fitzpatrick, J. Breitner, and S. Dekosky, "Prevalence of neuropsychiatric symptoms in dementia and mild cognitive impairment: results from the cardiovascular health study," Journal of the American Medical Association, vol. 288, no. 12, pp. 14751483, 2002.

[11] J. L. Cummings, M. Mega, K. Gray, S. Rosenberg-Thompson, D. A. Carusi, and J. Gornbein, "The neuropsychiatric inventory: comprehensive assessment of psychopathology in dementia," Neurology, vol. 44, no. 12, pp. 2308-2314, 1994.

[12] P. Aalten, F. R. J. Verhey, M. Boziki et al., "Consistency of neuropsychiatric syndromes across dementias: results from the European Alzheimer Disease Consortium: part II," Dementia and Geriatric Cognitive Disorders, vol. 25, no. 1, pp. 1-8, 2007.

[13] D. Seripa, F. Panza, M. Franceschi et al., "Non-apolipoprotein $\mathrm{E}$ and apolipoprotein E genetics of sporadic Alzheimer's disease," Ageing Research Reviews, vol. 8, no. 3, pp. 214-236, 2009.

[14] J. C. Lambert and P. Amouyel, "Genetic heterogeneity of Alzheimer's disease: complexity and advances," Psychoneuroendocrinology, vol. 32, no. 1, pp. S62-S70, 2007.

[15] D. Harold, R. Abraham, P. Hollingworth et al., "Genomewide association study identifies variants at CLU and PICALM associated with Alzheimer's disease," Nature Genetics, vol. 41, no. 10, pp. 1088-1093, 2009.

[16] J. C. Lambert, S. Heath, G. Even et al., "Genome-wide association study identifies variants at CLU and CR1 associated with Alzheimer's disease," Nature Genetics, vol. 41, no. 10, pp. 1094-1099, 2009.

[17] S. Seshadri, A. L. Fitzpatrick, M. A. Ikram et al., "Genomewide analysis of genetic loci associated with Alzheimer disease," Journal of the American Medical Association, vol. 303, no. 18, pp. 1832-1840, 2010.

[18] V. I. Zannis, P. W. Just, and J. L. Breslow, "Human apolipoprotein $\mathrm{E}$ isoprotein subclasses are genetically determined," American Journal of Human Genetics, vol. 33, no. 1, pp. 11-24, 1981.

[19] V. I. Zannis, J. L. Breslow, and G. Utermann, "Proposed nomenclature of apoE isoproteins, apoE genotypes, and phenotypes," Journal of Lipid Research, vol. 23, no. 6, pp. 911914, 1982.

[20] J. L. Breslow, J. McPherson, and A. L. Nussbaum, "Identification and DNA sequence of a human apolipoprotein E cDNA clone," Journal of Biological Chemistry, vol. 257, no. 24, pp. 14639-14641, 1982.

[21] H. K. Das, J. McPherson, and G. A. P. Bruns, "Isolation, characterization, and mapping to chromosome 19 of the human apolipoprotein E gene," Journal of Biological Chemistry, vol. 260, no. 10, pp. 6240-6247, 1985.

[22] Y.-K. Paik, D. J. Chang, and C. A. Reardon, "Nucleotide sequence and structure of the human apolipoprotein E gene," Proceedings of the National Academy of Sciences of the United States of America, vol. 82, no. 10, pp. 3445-3449, 1985.

[23] M. Emi, L. L. Wu, M. A. Robertson et al., "Genotyping and sequence analysis of apolipoprotein E isoforms," Genomics, vol. 3, no. 4, pp. 373-379, 1988.
[24] V. Solfrizzi, C. Capurso, A. D’Introno et al., "Lifestyle-related factors in predementia and dementia syndromes," Expert Review of Neurotherapeutics, vol. 8, no. 1, pp. 133-158, 2008.

[25] M. L. Levy, J. L. Cummings, L. A. Fairbanks, D. L. Sultzer, and G. W. Small, "Apolipoprotein E genotype and noncognitive symptoms in Alzheimer's disease," Biological Psychiatry, vol. 45, no. 4, pp. 422-425, 1999.

[26] D. Craig, D. J. Hart, K. McCool, S. P. McIlroy, and A. P. Passmore, "Apolipoprotein E e4 allele influences aggressive behaviour in Alzheimer's disease," Journal of Neurology, Neurosurgery and Psychiatry, vol. 75, no. 9, pp. 1327-1330, 2004.

[27] A. L. Pritchard, J. Harris, C. W. Pritchard et al., "The effect of the apolipoprotein E gene polymorphisms and haplotypes on behavioural and psychological symptoms in probable Alzheimer's disease," Journal of Neurology, Neurosurgery and Psychiatry, vol. 78, no. 2, pp. 123-126, 2007.

[28] B. Borroni, M. Grassi, C. Agosti et al., "Genetic correlates of behavioral endophenotypes in Alzheimer disease: role of COMT, 5-HTTLPR and APOE polymorphisms," Neurobiology of Aging, vol. 27, no. 11, pp. 1595-1603, 2006.

[29] P. Hollingworth, M. L. Hamshere, V. Moskvina et al., "Four components describe behavioral symptoms in 1,120 individuals with late-onset Alzheimer's disease," Journal of the American Geriatrics Society, vol. 54, no. 9, pp. 1348-1354, 2006.

[30] G. D'Onofrio, F. Panza, D. Seripa et al., "The APOE polymorphism in Alzheimer's disease patients with neuropsychiatric symptoms and syndromes," International Journal of Geriatric Psychiatry. In press.

[31] F. Panza, V. Frisardi, C. Capurso et al., "Late-Life depression, mild cognitive impairment, and dementia: possible continuum?" American Journal of Geriatric Psychiatry, vol. 18, no. 2, pp. 98-116, 2010.

[32] G. G. Potter and D. C. Steffens, "Contribution of depression to cognitive impairment and dementia in older adults," Neurologist, vol. 13, no. 3, pp. 105-117, 2007.

[33] G. S. Alexopoulos, "Depression in the elderly," Lancet, vol. 365, no. 9475, pp. 1961-1970, 2005.

[34] R. E. Wragg and D. V. Jeste, "Overview of depression and psychosis in Alzheimer's disease," American Journal of Psychiatry, vol. 146, no. 5, pp. 577-587, 1989.

[35] S. A. Beaudreau and R. O'Hara, "Late-life anxiety and cognitive impairment: a review," American Journal of Geriatric Psychiatry, vol. 16, no. 10, pp. 790-803, 2008.

[36] K. B. Wolitzky-Taylor, N. Castriotta, E. J. Lenze, M. A. Stanley, and M. G. Craske, "Anxiety disorders in older adults: a comprehensive review," Depression and Anxiety, vol. 27, no. 2, pp. 190-211, 2010.

[37] R. C. Kessler, P. Berglund, O. Demler, R. Jin, K. R. Merikangas, and E. E. Walters, "Lifetime prevalence and age-of-onset distributions of DSM-IV disorders in the national comorbidity survey replication," Archives of General Psychiatry, vol. 62, no. 6, pp. 593-602, 2005.

[38] D. A. Regier, J. H. Boyd, J. D. Burke Jr. et al., "One-month prevalence of mental disorders in the United States, Based on five epidemiologic catchment area sites," Archives of General Psychiatry, vol. 45, no. 11, pp. 977-986, 1988.

[39] G. Ramachandran, K. Marder, M. Tang et al., "A preliminary study of apolipoprotein E genotype and psychiatric manifestations of Alzheimer's disease," Neurology, vol. 47, no. 1, pp. 256-259, 1996. 
[40] R. Cacabelos, B. Rodríguez, C. Carrera, K. Beyer, J. I. Lao, and M. A. Sellers, "Behavioral changes associated with different apolipoprotein E genotypes in dementia," Alzheimer Disease and Associated Disorders, vol. 11, no. 4, pp. S27-S34, 1997.

[41] G. M. Murphy, J. Taylor, J. R. Tinklenberg, and J. A. Yesavage, "The apolipoprotein E $\varepsilon 4$ allele is associated with increased behavioral disturbance in Alzheimer's disease," American Journal of Geriatric Psychiatry, vol. 5, no. 1, pp. 88-89, 1997.

[42] K. R. R. Krishnan, L. A. Tupler, J. C. Ritchie et al., "Apolipoprotein E- $\in 4$ frequency in geriatric depression," Biological Psychiatry, vol. 40, no. 1, pp. 69-71, 1996.

[43] D. C. Steffens, B. L. Plassman, M. J. Helms, K. A. WelshBohmer, A. M. Saunders, and J. C. S. Breitner, "A twin study of late-onset depression and apolipoprotein E $\varepsilon 4$ as risk factors for Alzheimer's disease," Biological Psychiatry, vol. 41, no. 8, pp. 851-856, 1997.

[44] A. S. Rigaud, L. Traykov, L. Caputo et al., "Association of the apolipoprotein E $\varepsilon 4$ allele with late-onset depression," Neuroepidemiology, vol. 20, no. 4, pp. 268-272, 2001.

[45] R. S. Wilson, L. L. Barnes, C. F. Mendes De Leon et al., "Depressive symptoms, cognitive decline, and risk of AD in older persons," Neurology, vol. 59, no. 3, pp. 364-370, 2002.

[46] F. Irie, K. H. Masaki, H. Petrovitch et al., "Apolipoprotein E $\varepsilon 4$ allele genotype and the effect of depressive symptoms on the risk of dementia in men: the Honolulu-Asia aging study," Archives of General Psychiatry, vol. 65, no. 8, pp. 906-912, 2008.

[47] J. M. Kim, S. Y. Kim, K. Y. Bae et al., "Apolipoprotein E4 genotype and depressive symptoms as risk factors for dementia in an older Korean population," Psychiatry Investigation, vol. 7, no. 2, pp. 135-140, 2010.

[48] T. Müller-Thomsen, S. Arlt, S. Ganzer et al., "Depression in Alzheimer's disease might be associated with apolipoprotein E $\varepsilon 4$ allele frequency in women but not in men," Dementia and Geriatric Cognitive Disorders, vol. 14, no. 2, pp. 59-63, 2002.

[49] L. Delano-Wood, W. S. Houston, J. A. Emond et al., "APOE genotype predicts depression in women with Alzheimer's disease: a retrospective study," International Journal of Geriatric Psychiatry, vol. 23, no. 6, pp. 632-636, 2008.

[50] B. Reisberg, S. R. Auer, and I. M. Monteiro, "Behavioral pathology in Alzheimer's disease (BEHAVE-AD) rating scale," International Psychogeriatrics, vol. 8, no. 3, pp. 301308, 1996.

[51] J. L. Cummings, "Cognitive and behavioral heterogeneity in Alzheimer's disease: seeking the neurobiological basis," Neurobiology of Aging, vol. 21, no. 6, pp. 845-861, 2000.

[52] K. Shinosaki, T. Nishikawa, and M. Takeda, "Neurobiological basis of behavioral and psychological symptoms in dementia of the Alzheimer type," Psychiatry and Clinical Neurosciences, vol. 54, no. 6, pp. 611-620, 2000.

[53] C. Holmes, R. Levy, D. M. McLoughlin, J. F. Powell, and S. Lovestone, "Apolipoprotein E: non-cognitive symptoms and cognitive decline in late onset Alzheimer's disease," Journal of Neurology Neurosurgery and Psychiatry, vol. 61, no. 6, pp. 580-583, 1996.

[54] C. Holmes, D. M. McLoughlin, J. Powell, and S. Lovestone, "Reply," Journal of Neurology, Neurosurgery, and Psychiatry, vol. 63, no. 2, pp. 273-274, 1997.

[55] C. Holmes, C. Russ, G. Kirov et al., "Apolipoprotein E: Depressive illness, depressive symptoms, and Alzheimer's disease," Biological Psychiatry, vol. 43, no. 3, pp. 159-164, 1998.
[56] R. Cacabelos, B. Rodríguez, C. Carrera et al., "APOErelated frequency of cognitive and noncognitive symptoms in dementia," Methods and Findings in Experimental and Clinical Pharmacology, vol. 18, no. 10, pp. 693-706, 1996.

[57] M. Lehtovirta, H. Soininen, S. Helisalmi et al., "Clinical and neuropsychological characteristics in familial and sporadic Alzheimer's disease: relation to apolipoprotein E polymorphism," Neurology, vol. 46, no. 2, pp. 413-419, 1996.

[58] M. Cantillon, D. Harwood, W. Barker et al., "No association between apolipoprotein E genotype and late-onset depression in Alzheimer's disease," Biological Psychiatry, vol. 41, no. 2, pp. 246-248, 1997.

[59] G. Spalletta, S. Bernardini, L. Bellincampi, G. Federici, A. Trequattrini, and C. Caltagirone, "Delusion symptoms are associated with ApoE \&4 allelic variant at the early stage of Alzheimer's disease with late onset," European Journal of Neurology, vol. 13, no. 2, pp. 176-182, 2006.

[60] Y. Forsell, E. H. Corder, H. Basun, L. Lannfelt, M. Viitanen, and B. Winblad, "Depression and dementia in relation to apolipoprotein E polymorphism in a population sample age +75," Biological Psychiatry, vol. 42, no. 10, pp. 898-903, 1997.

[61] Y. Forsell, H. Basun, E. H. Corder, L. Lannfelt, and B. Winblad, "Psychotic symptoms and apolipoprotein E genotypes in an elderly population," Biological Psychiatry, vol. 44, no. 2, pp. 139-140, 1998.

[62] O. L. Lopez, M. I. Kamboh, J. T. Becker, D. I. Kaufer, and S. T. DeKosky, "The apolipoprotein E $\varepsilon 4$ allele is not associated with psychiatric symptoms or extrapyramidal signs in probable Alzheimer's disease," Neurology, vol. 49, no. 3, pp. 794-797, 1997.

[63] C. G. Lyketsos, L. Baker, A. Warren et al., "Depression, delusions, and hallucinations in Alzheimer's disease: no relationship to apolipoprotein E genotype," Journal of Neuropsychiatry and Clinical Neurosciences, vol. 9, no. 1, pp. 6467, 1997.

[64] N. Hirono, E. Mori, M. Yasuda et al., "Factors associated with psychotic symptoms in Alzheimer's disease," Journal of Neurology Neurosurgery and Psychiatry, vol. 64, no. 5, pp. 648-652, 1998.

[65] N. Hirono, E. Mori, M. Yasuda et al., "Lack of effect of apolipoprotein E E4 allele on neuropsychiatric manifestations in Alzheimer's disease," Journal of Neuropsychiatry and Clinical Neurosciences, vol. 11, no. 1, pp. 66-70, 1999.

[66] D. G. Harwood, W. W. Barker, R. L. Ownby, -. P. ST. George, and R. Duara, "Apolipoprotein-E (APO-E) genotype and symptoms of psychosis in Alzheimer's disease," American Journal of Geriatric Psychiatry, vol. 7, no. 2, pp. 119-123, 1999.

[67] C. Y. Liu, C. J. Hong, T. Y. Liu et al., "Lack of association between the apolipoprotein E genotype and depression in Alzheimer's disease," Journal of Geriatric Psychiatry and Neurology, vol. 15, no. 1, pp. 20-23, 2002.

[68] N. Scarmeas, J. Brandt, M. Albert et al., "Association between the APOE genotype and psychopathologic symptoms in Alzheimer's disease," Neurology, vol. 58, no. 8, pp. 1182-1188, 2002.

[69] T. Gabryelewicz, D. Religa, M. Styczynska et al., "Behavioural pathology in Alzheimer's disease with special reference to apolipoprotein E genotype," Dementia and Geriatric Cognitive Disorders, vol. 14, no. 3-4, pp. 208-212, 2002.

[70] R. A. Sweet, V. L. Nimgaonkar, B. Devlin, O. L. Lopez, and S. T. DeKosky, "Increased familial risk of the psychotic phenotype of Alzheimer disease," Neurology, vol. 58, no. 6, pp. 907-911, 2002. 
[71] D. Craig, D. J. Hart, S. P. Mcllroy, and A. P. Passmore, "Association analysis of apolipoprotein E genotype and risk of depressive symptoms in Alzheimer's disease," Dementia and Geriatric Cognitive Disorders, vol. 19, no. 2-3, pp. 154157, 2005.

[72] J. B. Chang, P. N. Wang, W. T. Chen et al., "ApoE $\varepsilon 4$ allele is associated with incidental hallucinations and delusions in patients with AD," Neurology, vol. 63, no. 6, pp. 1105-1107, 2004.

[73] J. Robertson, J. Curley, J. Kaye, J. Quinn, T. Pfankuch, and J. Raber, "apoE isoforms and measures of anxiety in probable $\mathrm{AD}$ patients and Apoe ${ }^{-/-}$mice," Neurobiology of Aging, vol. 26, no. 5, pp. 637-643, 2005.

[74] R. Monastero, E. Mariani, C. Camarda et al., "Association between apolipoprotein E $\varepsilon 4$ allele and apathy in probable Alzheimer's disease," Acta Psychiatrica Scandinavica, vol. 113, no. 1, pp. 59-63, 2006.

[75] W. M. Van Der Flier, S. Staekenborg, Y. A. L. Pijnenburg et al., "Apolipoprotein E genotype influences presence and severity of delusions and aggressive behavior in Alzheimer disease," Dementia and Geriatric Cognitive Disorders, vol. 23, no. 1, pp. 42-46, 2006.

[76] K. F. Zdanys, T. G. Kleiman, M. G. MacAvoy et al., "Apolipoprotein E $\varepsilon 4$ allele increases risk for psychotic symptoms in Alzheimer's disease," Neuropsychopharmacology, vol. 32, no. 1, pp. 171-179, 2007.

[77] M. P. Chopra, R. D. Landes, R. A. Jones, Z. L. Feldman, C. Beck, and S. T. Griffin, "Does the apolipoproten E $\varepsilon 4$ genotype influence the expression of depression with cognitive impairment?" International Journal of Geriatric Psychiatry, vol. 24, no. 6, pp. 650-652, 2009.

[78] M. Del Prete, S. Spaccavento, A. Craca, P. Fiore, and P. Angelelli, "Neuropsychiatric symptoms and the APOE genotype in Alzheimer's disease," Neurological Sciences, vol. 30, no. 5, pp. 367-373, 2009.

[79] D. L. Woods, B. Bushnell, H. Kim, D. Geschwind, and J. Cummings, "Apolipoprotein epsilon4 status is associated with behavioral symptoms in nursing home residents with dementia," International Psychogeriatrics, vol. 21, supplement 4, pp. 722-728, 2009.

[80] C. Ballard, H. Massey, H. Lamb, and C. Morris, "Apolipoprotein E: non-cognitive symptoms and cognitive decline in late onset Alzheimer's disease," Journal of Neurology, Neurosurgery, and Psychiatry, vol. 63, no. 2, pp. 273-274, 1997.

[81] L. G. Apostolova and J. L. Cummings, "Neuropsychiatric manifestations in mild cognitive impairment: A systematic review of the literature," Dementia and Geriatric Cognitive Disorders, vol. 25, no. 2, pp. 115-126, 2008.

[82] V. R. Porter, W. G. Buxton, L. A. Fairbanks et al., "Frequency and characteristics of anxiety among patients with Alzheimer's disease and related dementias," Journal of Neuropsychiatry and Clinical Neurosciences, vol. 15, no. 2, pp. 180-186, 2003.

[83] L. A. Farrer, L. A. Cupples, J. L. Haines et al., "Effects of age, sex, and ethnicity on the association between apolipoprotein E genotype and Alzheimer disease: a meta-analysis," Journal of the American Medical Association, vol. 278, no. 16, pp. 1349-1356, 1997.

[84] J. Raber, "Role of apolipoprotein E in anxiety," Neural Plasticity, vol. 2007, Article ID 91236, 7 pages, 2007.

[85] J. A. Siegel, G. E. Haley, and J. Raber, "Apolipoprotein E isoform-dependent effects on anxiety and cognition in female TR mice," Neurobiology of Aging. In press.
[86] R. S. Marin, “Apathy: a neuropsychiatric syndrome," Journal of Neuropsychiatry and Clinical Neurosciences, vol. 3, no. 3, pp. 243-254, 1991.

[87] S. Ishii, N. Weintraub, and J. R. Mervis, "Apathy: a common psychiatric syndrome in the elderly," Journal of the American Medical Directors Association, vol. 10, no. 6, pp. 381-393, 2009.

[88] American Psychiatric Association, Diagnostic and Statistical Manual of Mental Disorders, American Psychiatric Publishing, Arlington, Va, USA, 4th edition, 2004.

[89] A. M. Landes, S. D. Sperry, M. E. Strauss, and D. S. Geldmacher, "Apathy in Alzheimer's disease," Journal of the American Geriatrics Society, vol. 49, no. 12, pp. 1700-1707, 2001.

[90] M. L. Levy, J. L. Cummings, L. A. Fairbanks et al., "Apathy is not depression," Journal of Neuropsychiatry and Clinical Neurosciences, vol. 10, no. 3, pp. 314-319, 1998.

[91] S. E. Starkstein, L. Sabe, S. Vázquez et al., "Neuropsychological, psychiatric, and cerebral blood flow findings in vascular dementia and Alzheimer's disease," Stroke, vol. 27, no. 3, pp. 408-414, 1996.

[92] G. D’Onofrio, D. Sancarlo, F. Panza et al., "Neuropsychiatric symptoms in patients with Alzheimer's disease and vascular dementia," Current Alzheimer Research. In press.

[93] R. A. Sweet, V. L. Nimgaonkar, B. Devlin, and D. V. Jeste, "Psychotic symptoms in Alzheimer disease: evidence for a distinct phenotype," Molecular Psychiatry, vol. 8, no. 4, pp. 383-392, 2003.

[94] D. V. Jeste, T. W. Meeks, D. S. Kim, and G. S. Zubenko, "Research agenda for DSM-V: diagnostic categories and criteria for neuropsychiatric syndromes in dementia," Journal of Geriatric Psychiatry and Neurology, vol. 19, no. 3, pp. 160171, 2006.

[95] S. A. Ropacki and D. V. Jeste, "Epidemiology of and risk factors for psychosis of Alzheimer's disease: a review of 55 studies published from 1990 to 2003," American Journal of Psychiatry, vol. 162, no. 11, pp. 2022-2030, 2005.

[96] C. G. Lyketsos, J. M. E. Sheppard, M. Steinberg et al., "Neuropsychiatric disturbance in Alzheimer's disease clusters into three groups: the Cache County Study," International Journal of Geriatric Psychiatry, vol. 16, no. 11, pp. 1043-1053, 2001.

[97] D. V. Jeste and S. I. Finkel, "Psychosis of Alzheimer's disease and related dementias: diagnostic criteria for a distinct syndrome," American Journal of Geriatric Psychiatry, vol. 8, no. 1, pp. 29-34, 2000.

[98] S. A. Bacanu, B. Devlin, K. V. Chowdari, S. T. DeKosky, V. L. Nimgaonkar, and R. A. Sweet, "Heritability of psychosis in Alzheimer disease," American Journal of Geriatric Psychiatry, vol. 13, no. 7, pp. 624-627, 2005.

[99] R. A. Sweet, M. I. Kamboh, S. R. Wisniewski et al., "Apolipoprotein E and alpha-1-antichymotrypsin genotypes do not predict time to psychosis in Alzheimer's disease," Journal of Geriatric Psychiatry and Neurology, vol. 15, no. 1, pp. 24-30, 2002.

[100] B. Nacmias, A. Tedde, P. Forleo et al., "Association between 5-HT receptor polymorphism and psychotic symptoms in Alzheimer's disease," Biological Psychiatry, vol. 50, no. 6, pp. 472-475, 2001.

[101] M. F. Weiner, G. Vega, R. C. Risser et al., "Apolipoprotein E⿺4, other risk factors, and course of Alzheimer's disease," Biological Psychiatry, vol. 45, no. 5, pp. 633-638, 1999. 
[102] P. Aalten, M. E. De Vugt, R. Lousberg et al., "Behavioral problems indementia: a factor analysis of the neuropsychiatric inventory," Dementia and Geriatric Cognitive Disorders, vol. 15, no. 2, pp. 99-105, 2003.

[103] J. Cohen-Mansfield, "Nonpharmacologic interventions for inappropriate behaviors in dementia: a review, summary, and critique," American Journal of Geriatric Psychiatry, vol. 9, no. 4, pp. 361-381, 2001.

[104] J. Cohen-Mansfield and P. Werner, "Longitudinal predictors of non-aggressive agitated behaviors in the elderly," International Journal of Geriatric Psychiatry, vol. 14, no. 10, pp. 831844, 1999.

[105] L. H. Deutsch, F. W. Bylsma, B. W. Rovner, C. Steele, and M. F. Folstein, "Psychosis and physical aggression in probable Alzheimer's disease," American Journal of Psychiatry, vol. 148, no. 9, pp. 1159-1163, 1991.

[106] M. A. DeMichele-Sweet and R. A. Sweet, "Genetics of psychosis in Alzheimer's disease: a review," Journal of Alzheimer's Disease, vol. 19, no. 3, pp. 761-780, 2010.

[107] B. Borroni, C. Costanzi, and A. Padovani, "Genetic susceptibility to behavioural and psychological symptoms in alzheimer disease," Current Alzheimer Research, vol. 7, no. 2, pp. 158-164, 2010.

[108] S. López-León, A. C. J. W. Janssens, A. M. González-Zuloeta Ladd et al., "Meta-analyses of genetic studies on major depressive disorder," Molecular Psychiatry, vol. 13, no. 8, pp. 772-785, 2008.

[109] M. O. McCarron, D. Delong, and M. J. Alberts, "APOE genotype as a risk factor for ischemic cerebrovascular disease: a meta-analysis," Neurology, vol. 53, no. 6, pp. 1308-1311, 1999.

[110] H. Sawada, F. Udaka, Y. Izumi et al., "Cerebral white matter lesions are not associated with apoE genotype but with age and female sex in Alzheimer's disease," Journal of Neurology Neurosurgery and Psychiatry, vol. 68, no. 5, pp. 653-656, 2000.

[111] J. Davignon, J. S. Cohn, L. Mabile, and L. Bernier, "Apolipoprotein E and atherosclerosis: insight from animal and human studies," Clinica Chimica Acta, vol. 286, no. 1-2, pp. 115-143, 1999.

[112] E. Brscic, S. Bergerone, A. Gagnor et al., "Acute myocardial infarction in young adults: prognostic role of angiatensinconverting enzyme, angiotensin II type I receptor, apolipoprotein E, endothelial constitutive nitric oxide synthase, and glycoprotein IIIa genetic polymorphisms at medium-term follow-up," American Heart Journal, vol. 139, no. 6, pp. 979-984, 2000.

[113] F. E. De Leeuw, F. Richard, J. C. De Groot et al., "Interaction between hypertension, apoE, and cerebral white matter lesions," Stroke, vol. 35, no. 5, pp. 1057-1060, 2004.

[114] G. S. Alexopoulos, B. S. Meyers, R. C. Young, T. Kakuma, D. Silbersweig, and M. Charlson, "Clinically defined vascular depression," American Journal of Psychiatry, vol. 154, no. 4, pp. 562-565, 1997.

[115] G. S. Alexopoulos, S. K. Schultz, and B. D. Lebowitz, "Latelife depression: a model for medical classification," Biological Psychiatry, vol. 58, no. 4, pp. 283-289, 2005.

[116] K. A. Treiber, C. G. Lyketsos, C. Corcoran et al., "Vascular factors and risk for neuropsychiatric symptoms in Alzheimer's disease: the Cache County Study," International Psychogeriatrics, vol. 20, no. 3, pp. 538-553, 2008.

[117] J. O'Brien, R. Perry, R. Barber, A. Gholkar, and A. Thomas, "The association between white matter lesions on magnetic resonance imaging and noncognitive symptoms," Annals of the New York Academy of Sciences, vol. 903, pp. 482-489, 2000.

[118] Y. E. Geda, D. S. Knopman, D. A. Mrazek et al., "Depression, apolipoprotein E genotype, and the incidence of mild cognitive impairment: a prospective cohort study," Archives of Neurology, vol. 63, no. 3, pp. 435-440, 2006.

[119] M. Michikawa, QI. W. Fan, I. Isobe, and K. Yanagisawa, "Apolipoprotein E exhibits isoform-specific promotion of lipid efflux from astrocytes and neurons in culture," Journal of Neurochemistry, vol. 74, no. 3, pp. 1008-1016, 2000.

[120] T. Arendt, C. Schindler, M. K. Brückner et al., "Plastic neuronal remodeling is impaired in patients with Alzheimer's disease carrying apolipoprotein $\varepsilon 4$ allele," Journal of Neuroscience, vol. 17, no. 2, pp. 516-529, 1997.

[121] F. C. Crawford, R. D. Vanderploeg, M. J. Freeman et al., "APOE genotype influences acquisition and recall following traumatic brain injury," Neurology, vol. 58, no. 7, pp. 11151118, 2002.

[122] A. H. Craig, J. L. Cummings, L. Fairbanks et al., "Cerebral blood flow correlates of apathy in Alzheimer disease," Archives of Neurology, vol. 53, no. 11, pp. 1116-1120, 1996.

[123] O. Migneco, M. Benoit, P. M. Koulibaly et al., "Perfusion brain SPECT and statistical parametric mapping analysis indicate that apathy is a cingulate syndrome: a study in Alzheimer's disease and nondemented patients," NeuroImage, vol. 13, no. 5, pp. 896-902, 2001.

[124] S. Tekin, M. S. Mega, D. M. Masterman et al., "Orbitofrontal and anterior cingulate cortex neurofibrillary tangle burden is associated with agitation in Alzheimer disease," Annals of Neurology, vol. 49, no. 3, pp. 355-361, 2001.

[125] S. Mcpherson, L. Fairbanks, S. Tiken, J. L. Cummings, and C. Back-Madruga, "Apathy and executive function in Alzheimer's disease," Journal of the International Neuropsychological Society, vol. 8, no. 3, pp. 373-381, 2002.

[126] P. A. Boyle and P. F. Malloy, "Treating apathy in Alzheimer's disease," Dementia and Geriatric Cognitive Disorders, vol. 17, no. 1-2, pp. 91-99, 2004.

[127] H. Soininen, O. Kosunen, S. Helisalmi et al., "A severe loss of choline acetyltransferase in the frontal cortex of Alzheimer patients carrying apolipoprotein $\varepsilon 4$ allele," Neuroscience Letters, vol. 187, no. 2, pp. 79-82, 1995.

[128] H. Yamaguchi, S. Sugihara, A. Ogawa, N. Oshima, and Y. Ihara, "Alzheimer $\beta$ amyloid deposition enhanced by ApoE $\varepsilon 4$ gene precedes neurofibrillary pathology in the frontal association cortex of nondemented senior subjects," Journal of Neuropathology and Experimental Neurology, vol. 60, no. 7, pp. 731-739, 2001.

[129] D. E. Schmechel, A. M. Saunders, W. J. Strittmatter et al., "Increased amyloid $\beta$-peptide deposition in cerebral cortex as a consequence of apolipoprotein E genotype in late-onset Alzheimer disease," Proceedings of the National Academy of Sciences of the United States of America, vol. 90, no. 20, pp. 9649-9653, 1993.

[130] T. Gomez-Isla, H. L. West, G. W. Rebeck et al., "Clinical and pathological correlates of apolipoprotein $\varepsilon 4$ in Alzheimer's disease," Annals of Neurology, vol. 39, no. 1, pp. 62-70, 1996.

[131] G. S. Zubenko, J. Moossy, A. J. Martinez et al., "Neuropathologic and neurochemical correlates of psychosis in primary dementia," Archives of Neurology, vol. 48, no. 6, pp. 619-624, 1991.

[132] R. A. Sweet, R. L. Hamilton, O. L. Lopez et al., "Psychotic symptoms in Alzheimer's disease are not associated with more severe neuropathologic features," International Psychogeriatrics, vol. 12, no. 4, pp. 547-558, 2000. 
[133] J. Poirier, M. C. Delisle, R. Quirion et al., "Apolipoprotein $\mathrm{E} 4$ allele as a predictor of cholinergic deficits and treatment outcome in Alzheimer disease," Proceedings of the National Academy of Sciences of the United States of America, vol. 92, no. 26, pp. 12260-12264, 1995.

[134] J. L. Cummings and D. Kaufer, "Neuropsychiatric aspects of Alzheimer's disease: the cholinergic hypothesis revisited," Neurology, vol. 47, no. 4, pp. 876-883, 1996.

[135] H. Forstl, A. Burns, R. Levy, and N. Cairns, "Neuropathological correlates of psychotic phenomena in confirmed Alzheimer's disease," British Journal of Psychiatry, vol. 164, pp. 53-59, 1994.

[136] S. E. Starkstein, S. Vazquez, G. Petracca et al., "A SPECT study of delusions in Alzheimer's disease," Neurology, vol. 44, no. 11, pp. 2055-2059, 1994.

[137] K. U. Lee, J. S. Lee, KI. W. Kim et al., "Influence of the apolipoprotein E type 4 allele on cerebral glucose metabolism in Alzheimer's disease patients," Journal of Neuropsychiatry and Clinical Neurosciences, vol. 15, no. 1, pp. 78-83, 2003.

[138] C. H. Van Dyck, J. Gelernter, M. G. MacAvoy et al., "Absence of an apolipoprotein E $\varepsilon 4$ allele is associated with increased parietal regional cerebral blood flow asymmetry in Alzheimer disease," Archives of Neurology, vol. 55, no. 11, pp. 1460-1466, 1998.

[139] M. Lehtovirta, H. Soininen, M. P. Laakso et al., "SPECT and MRI analysis in Alzheimer's disease: relation to apolipoprotein E $\varepsilon 4$ allele," Journal of Neurology Neurosurgery and Psychiatry, vol. 60, no. 6, pp. 644-649, 1996.

[140] M. Hashimoto, M. Yasuda, S. Tanimukai et al., "Apolipoprotein $\mathrm{E} \varepsilon 4$ and the pattern of regional brain atrophy in Alzheimer's disease," Neurology, vol. 57, no. 8, pp. 1461-1466, 2001.

[141] M. Basso, J. Gelernter, J. Yang et al., "Apolipoprotein E epsilon4 is associated with atrophy of the amygdala in Alzheimer's disease," Neurobiology of Aging, vol. 27, no. 10, pp. 1416-1424, 2006.

[142] M. Kanai, M. Shizuka, K. Urakami et al., "Apolipoprotein $\mathrm{E} 4$ accelerates dementia and increases cerebrospinal fluid tau levels in Alzheimer's disease," Neuroscience Letters, vol. 267, no. 1, pp. 65-68, 1999.

[143] M. J. McNamara, T. Gomez-Isla, and B. T. Hyman, "Apolipoprotein $\mathrm{E}$ genotype and deposits of $\mathrm{A} \beta 40$ and $\mathrm{A} \beta 42$ in Alzheimer disease," Archives of Neurology, vol. 55, no. 7, pp. 1001-1004, 1998.

[144] S. Tekin, M. S. Mega, D. M. Masterman et al., "Orbitofrontal and anterior cingulate cortex neurofibrillary tangle burden is associated with agitation in Alzheimer disease," Annals of Neurology, vol. 49, no. 3, pp. 355-361, 2001.

[145] N. Hirono, M. S. Mega, I. D. Dinov, F. Mishkin, and J. L. Cummings, "Left frontotemporal hypoperfusion is associated with aggression in patients with dementia," Archives of Neurology, vol. 57, no. 6, pp. 861-866, 2000.

[146] B. Lawlor, "Serotonin and Alzheimer's disease," Psychiatric Annals, vol. 20, pp. 567-570, 1990.

[147] K. J. Reinikainen, H. Soininen, and P. J. Reikkinen, "Neurotransmitter changes in Alzheimer's dementia and agitation," Journal of Neuroscience Research, vol. 27, no. 4, pp. 576-586, 1990.

[148] C. Reitz and R. Mayeux, "Endophenotypes in normal brain morphology and Alzheimer's disease: a review," Neuroscience, vol. 164, no. 1, pp. 174-190, 2009. 


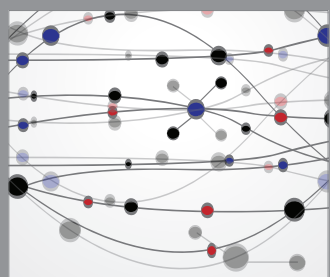

The Scientific World Journal
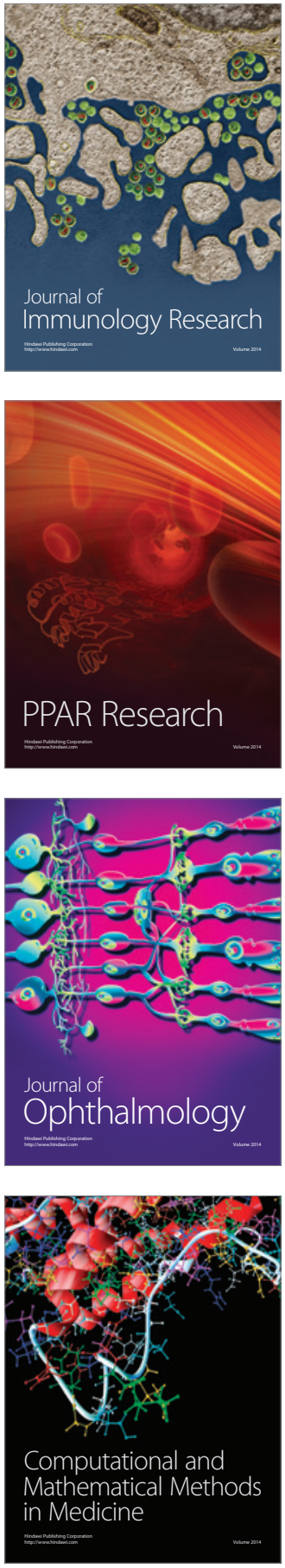

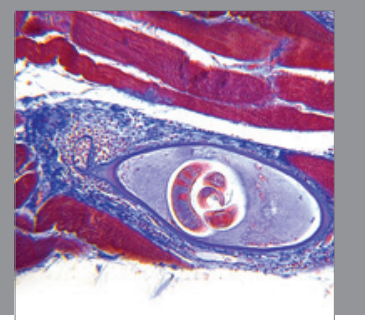

Gastroenterology

Research and Practice
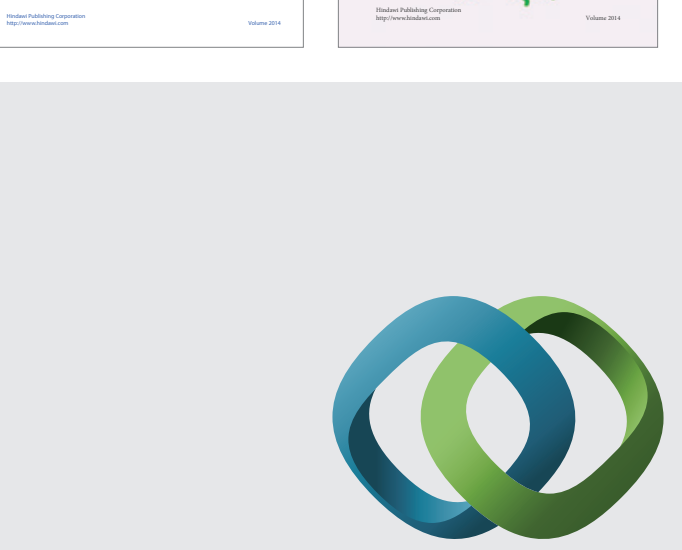

\section{Hindawi}

Submit your manuscripts at

http://www.hindawi.com
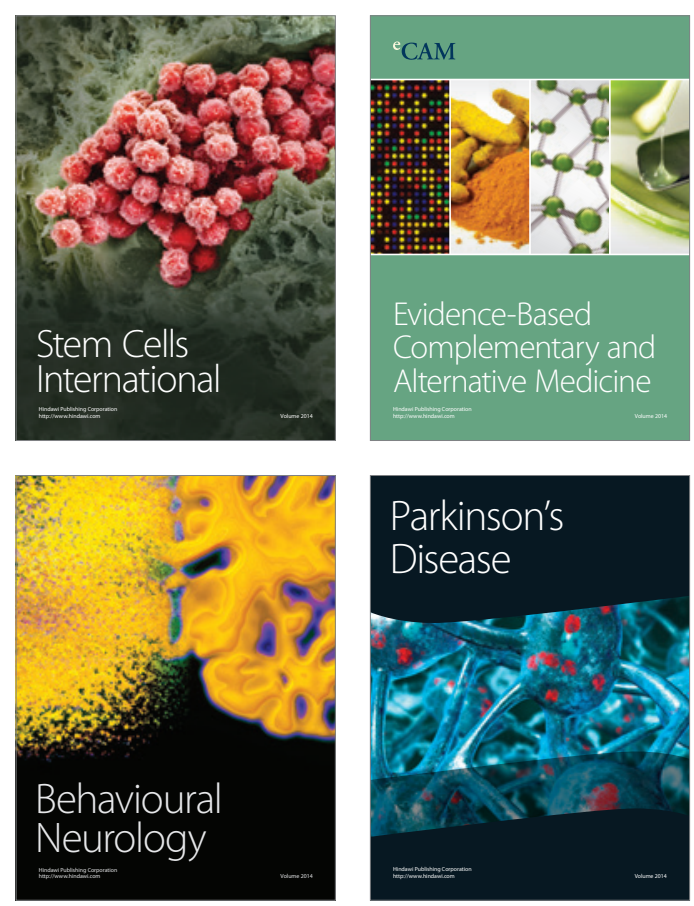

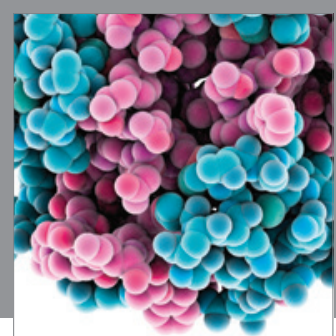

Journal of
Diabetes Research

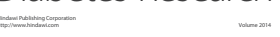

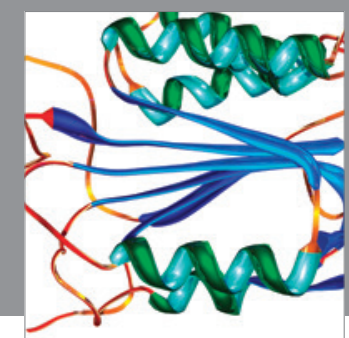

Disease Markers
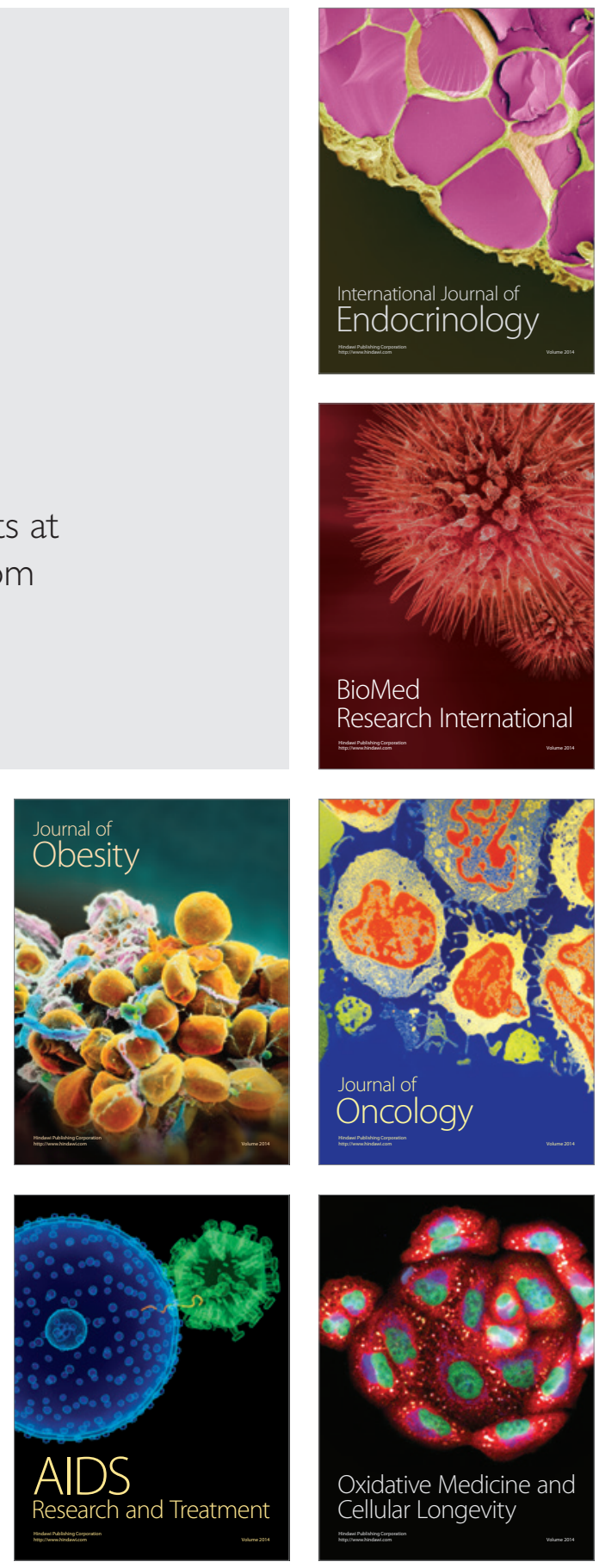